\title{
Adipose-derived stem cell-released osteoprotegerin protects cardiomyocytes from reactive oxygen species-induced cell death
}

Jiyun Lee ${ }^{1 \dagger}$, Seahyung Lee ${ }^{2 \dagger}$, Chang Youn Lee ${ }^{3}$, Hyang-Hee Seo ${ }^{1}$, Sunhye Shin ${ }^{3}$, Jung-Won Choi ${ }^{2,4}$, Sang Woo Kim², Jong-Chul Park ${ }^{1,5}$, Soyeon Lim ${ }^{2^{*}}$ and Ki-Chul Hwang ${ }^{2^{*}}$

\begin{abstract}
Background: The paracrine effect is likely the major mechanism of the adipose-derived stem cell (ASC)-mediated cardioprotective effect. However, the exact composition and nature of ASC-released paracrine factors remain elusive. In the present study, we examined the effect of osteoprotegerin (OPG), a stem cell-released decoy receptor for death ligand, on the survival of cardiomyocytes exposed to oxidative stress.

Methods: The production of OPG from ASCs under oxidative stress was determined by ELISA and immunohistochemistry. The effects of OPG and the OPG-containing conditioned media of ASCs on the survival of cardiomyocytes were determined using a cell viability assay.

Results: Hydrogen peroxide $\left(\mathrm{H}_{2} \mathrm{O}_{2}\right)$ significantly increased $\mathrm{OPG}$ production from ASCs in vitro, and OPG production from the ASCs transplanted into the ischemia-reperfusion-injured heart was also observed. OPG significantly attenuated cardiomyocyte death in vitro. OPG-containing conditioned media of ASCs also significantly protected cardiomyocytes. Delivery of siRNA specific to OPG significantly decreased the OPG production of ASCs, and also offset the protective effect of the conditioned media of ASCs.

Conclusions: Our study strongly suggests that OPG is one of the prosurvival factors released from ASCs that may contribute to the ASC-mediated cardioprotection and calls for further studies to elucidate detailed underlying mechanisms.
\end{abstract}

Keywords: Osteoprotegerin, Oxidative stress, Cardiomyocyte survival, Stem cell

\section{Background}

Previous studies have reported the cardioprotective effect of adipose-derived stem cells (ASCs) [1,2]. Evidence suggests that the regenerative effect of transplanted stem cells is mainly mediated by paracrine factors $[3,4]$, and stem cell-released factors varied depending on the source of stem cells and the stimuli they were exposed to $[5,6]$. Therefore, it is important to identify soluble factors contributing to the beneficial effect (i.e., host cell protection) of stem cells under a specified condition

\footnotetext{
* Correspondence: slim724@cku.ac.kr; kchwang@cku.ac.kr

${ }^{\dagger}$ Equal contributors

${ }^{2}$ Institute for Bio-Medical Convergence, College of Medicine, Catholic

Kwandong University, Gangneung, Gangwon-do, Korea

Full list of author information is available at the end of the article
}

because a clinically effective stem cell-based therapeutic strategy can be developed based on such information. Osteoprotegerin (OPG) is known to be produced by stem cells, fibroblasts, and endothelial cells [7]. OPG is a soluble decoy receptor that binds to tumor necrosis factor-related apoptosis-inducing ligand (TRAIL), thereby neutralizing TRAIL-mediated apoptotic signaling [8]. TRAIL initiates signaling cascade by binding to corresponding receptors such as TRAIL-R1, TRAIL-R2, TRAIL-R3, and TRAIL-R4 [9]. TRAIL-R1 and TRAILR2 can promote cell death signaling cascades, while TRAIL-R3 and TRAIL-R4 antagonize the TRAIL-R1 and TRAIL-R2-mediated apoptotic signaling by competitively binding to TRAIL [10]. In the present study, 
we examined the effect of OPG on the survival of cardiomyocytes exposed to oxidative stress.

\section{Methods \\ Culture of ASCs and $\mathrm{H} 9 \mathrm{c} 2$ cells}

Four vials of ASCs from four different human donors (StemPro human adipose-derived stem cells) were purchased from Invitrogen (Carlsbad, CA, USA), and rat cardiomyoblast cell line $\mathrm{H} 9 \mathrm{c} 2$ cells were purchased from ATCC (Manassas, VA, USA). ASCs and H9c2 cells were maintained according to the manufacturer's instructions. We used low-glucose Dulbecco's modified Eagle's medium (DMEM; Gibco, Waltham, MA, USA) and high-glucose DMEM (Gibco) containing 10\% fetal bovine serum (FBS; Gibco) and 1\% penicillin-streptomycin (Gibco) for ASCs and H9c2 cells, respectively.

\section{Isolation rat neonatal ventricular cardiomyocytes}

All experimental procedures for animal studies were approved by the committee for the care and use of laboratory animals of Catholic Kwandong University, and were performed in accordance with the committee's guidelines and regulations (CKU01-2015-003-1). Neonatal rat ventricular cardiomyocytes were isolated and purified by enzymatic methods following a protocol published previously [11].

\section{Ischemia-reperfusion injury and transplantation of ASCs}

Male 8-week-old Sprague-Dawley rats (250 g) were used. The animals were put under anesthesia with zoletil $(30 \mathrm{mg} / \mathrm{kg})$ and xylazine $(10 \mathrm{mg} / \mathrm{kg})$. The left anterior descending coronary artery was occluded using a 6-0 silk suture (Johnson \& Johnson, New Brunswick, NJ, USA). After $60 \mathrm{~min}$ of occlusion, the left anterior descending coronary artery was released for reperfusion, followed by cell transplantation. For transplantation, $1 \times 10^{6}$ cells were suspended in $30 \mu \mathrm{l}$ PBS and injected to border zone using a $0.3-\mathrm{ml}$ insulin syringe (BD Pharmingen, Franklin Lakes, NJ, USA).

\section{Statistical analyses}

Quantitative data were expressed as the means \pm SD of at least three independent experiments. For statistical analysis, one-way ANOVA with Bonferroni correction was performed using OriginPro 8 SR4 software (version 8.0951; OriginLab Corporation, Northampton, MA, USA) if there were more than three groups. $p<0.05$ was considered statistically significant.

Additional methods are available in Additional file 1.

\section{Results}

Hydrogen peroxide induced apoptosis of cardiomyocytes Hydrogen peroxide $\left(\mathrm{H}_{2} \mathrm{O}_{2}\right)$, a member of endogenous reactive oxygen species (ROS), has been used to simulate oxidative stress $[12,13]$. When H9c2 and primary cultured rat cardiomyocytes were treated with increasing concentration of $\mathrm{H}_{2} \mathrm{O}_{2}$ for 48 hours, the viability of both $\mathrm{H} 9 \mathrm{c} 2$ (Additional file 2: Figure S1A) and primary (Additional file 2: Figure $\mathrm{S} 1 \mathrm{~B}$ ) cardiomyocytes significantly decreased with $\mathrm{H}_{2} \mathrm{O}_{2}$ at a concentration of $100 \mu \mathrm{M}$ or higher. However, primary cardiomyocytes were more resistant to ROS than $\mathrm{H} 9 \mathrm{c} 2$ cardiomyocytes. Therefore, we mainly used H9c2 cardiomyocytes, which have been used as an alternative to primary cultured cardiomyocytes [14], to clearly demonstrate the prosurvival effect of OPG.

To confirm that the $\mathrm{H}_{2} \mathrm{O}_{2}$-induced cell death was oxidative stress mediated, the cells were pretreated with the well-established antioxidant $N$-acetyl-L-cystein (NAC) [15]. NAC pretreatment attenuated $\mathrm{H}_{2} \mathrm{O}_{2}$-induced activation of caspase 3 and 8 (Additional file 2: Figure S1C) and also significantly attenuated $\mathrm{H}_{2} \mathrm{O}_{2}$-induced decrease of $\mathrm{H} 9 \mathrm{c} 2$ viability (Additional file 2: Figure S1D). Furthermore, NAC pretreatment decreased the number of apoptotic propidium iodide (PI)/Annexin V double-stained cells [16] (Additional file 2: Figure $\mathrm{S} 1 \mathrm{E}$ ). Interestingly, $\mathrm{H}_{2} \mathrm{O}_{2}$ concentration up to $200 \mu \mathrm{M}$ did not decrease the viability of ASCs (Additional file 3: Figure S2).

\section{Oxidative stress increased OPG production from ASCs}

Both $\mathrm{H}_{2} \mathrm{O}_{2}$ and TGF- $\beta 1$, another soluble factor commonly present in damaged heart [17], significantly increased the OPG production of ASCs without decreasing viability (Fig. 1a). Also, $\mathrm{H}_{2} \mathrm{O}_{2}$ significantly increased mRNA expression of OPG and TRAIL receptor 3 (TRAIL-R3) (Additional file 4: Figure S3), which attenuates TRAIL-induced apoptosis [18]. In the ischemia-reperfusion (I/R)-injured heart without ASC transplantation, OPG expression was marginal only at day 1 after I/R injury (Fig. 1b). However, in the ASC transplantation group, prominent OPG expression was observed in the vicinity of transplanted ASCs, which gradually decreased with time (Fig. 1c).

\section{OPG protected cardiomyocytes from ROS-induced cell death}

To examine the effect of OPG on cardiomyocyte viability under oxidative stress, the cells were exposed to $\mathrm{H}_{2} \mathrm{O}_{2}$ with or without OPG (1.5 and $3 \mathrm{ng} / \mathrm{ml})$ treatment. OPG treatment significantly protected from $\mathrm{H}_{2} \mathrm{O}_{2}$ (Fig. 2a) and suppressed activation of caspase 8 without affecting the expression of TRAIL-R2 (Fig. 2b). Both ASC conditioned media with or without 48 hours of $\mathrm{H}_{2} \mathrm{O}_{2}$ $(100 \mu \mathrm{M})$ conditioning (designated as $\mathrm{H}_{2} \mathrm{O}_{2} \mathrm{CM}$ and NorCM, respectively) significantly attenuated $\mathrm{H}_{2} \mathrm{O}_{2}$-induced decrease of viability in both $\mathrm{H} 9 \mathrm{c} 2$ (Fig. 2c) and primary (Fig. 2d) cardiomyocytes. Between NorCM and $\mathrm{H}_{2} \mathrm{O}_{2} \mathrm{CM}, \mathrm{H}_{2} \mathrm{O}_{2} \mathrm{CM}$ was more effective to prevent $\mathrm{H}_{2} \mathrm{O}_{2}$-induced cardiomyocyte death. 

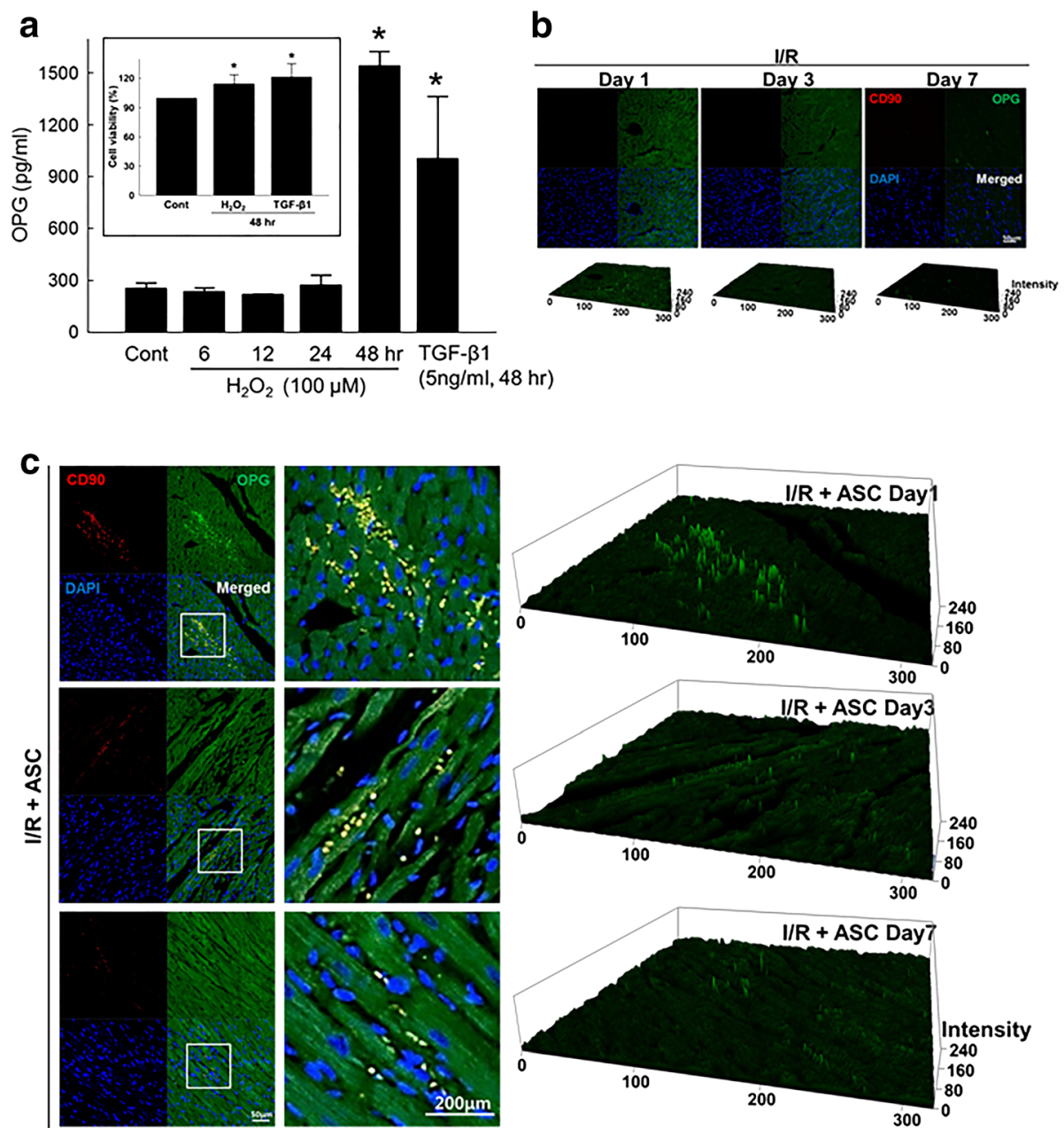

Fig. 1 Oxidative stress induced OPG secretion from ACSs. (a) Amount of OPG secreted from ASCs exposed to $\mathrm{H}_{2} \mathrm{O}_{2}(100 \mu M$ M) determined using an ELISA kit specific to human OPG. Conditioned media of ASCs exposed to $\mathrm{H}_{2} \mathrm{O}_{2}$ up to 48 hours were used for the analysis. TGF- $\beta 1$ ( $5 \mathrm{ng} / \mathrm{ml}$ ) was included as a soluble factor commonly present in damaged heart. Inset: viability of ASCs treated with $\mathrm{H}_{2} \mathrm{O}_{2}(100 \mu \mathrm{M})$ or TGF- $\beta 1$ ( $\left.5 \mathrm{ng} / \mathrm{ml}\right)$ for 48 hours. ${ }^{*} p<0.05$ compared to untreated control. (b) Expression of OPG in ischemia-reperfusion (I/R)-injured rat heart examined by immunofluorescence staining. I/R-injured rat heart was collected 1, 3, and 7 days after the injury without ASC transplantation, and damaged heart was stained with antibodies specific to CD90 (red), a stem cell marker, and OPG (green). Nucleus was stained with DAPI (blue). (c) Expression of OPG in I/R-injured heart with ASC transplantation $\left(1 \times 10^{6} \mathrm{cells} / \mathrm{head}\right)$. Two-dimensional immunofluorescence images were converted to $2.5 \mathrm{D}$ topological view images for clear presentation of staining intensity among groups. ASC adipose-derived stem cell, OPG osteoprotegerin, TGF- $\beta 1$ transforming growth factor beta 1 (Color figure online)

\section{Downregulation of OPG offset cell protective effect of ASC conditioned media}

To validate whether the cell protective effect of the ASC conditioned media was OPG mediated, siRNA specific to OPG was utilized. Delivery of OPG-specific siRNA to ASCs significantly attenuated OPG mRNA expression (Fig. 3a) and decreased OPG production (Fig. 3b). OPGspecific siRNA had no negative effect on the cell viability of ASCs (Fig. 3c). However, when siRNA specific to TRAIL-R3 was codelivered with OPG-specific siRNA, the viability of ASCs significantly decreased (Additional file 5: Figure S4). Finally, $\mathrm{H}_{2} \mathrm{O}_{2} \mathrm{CM}$ obtained from OPGspecific siRNA-treated ASCs showed decreased protective effect on cardiomyocytes exposed to $\mathrm{H}_{2} \mathrm{O}_{2}$ (Fig. 3d).

\section{Discussion}

It has been reported that TRAIL was released from the postischemic heart soon after the onset of reperfusion [19]. Considering ROS production, a major cause of myocardial cell death in I/R injury [20], is an early event in myocardial reperfusion injury, TRAIL released at the onset of reperfusion may by associated with increased ROS and subsequent myocardial cell death in the I/R-injured heart. Therefore, we hypothesized that ASCs transplanted into damaged heart (i.e., I/R-injured heart where excessive oxidative stress causes cardiac cell death [21-23]) secrete OPG, and in turn the ASC-released OPG prevents host cardiomyocyte death by antagonizing TRAIL signaling, which has never been tested. 

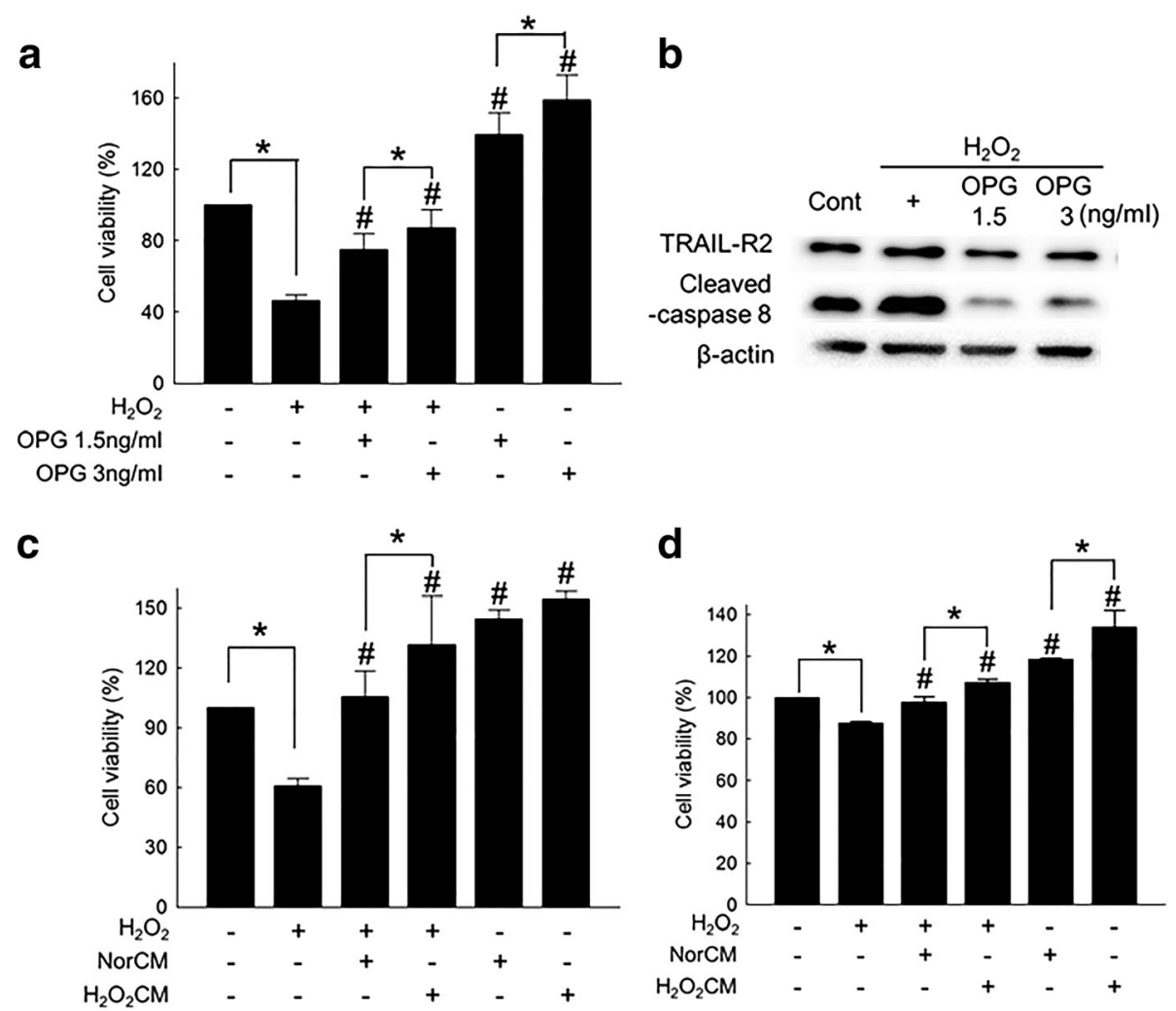

Fig. $2 \mathrm{OPG}$ protected cardiomyocytes from ROS-induced cell death. (a) Effect of OPG on $\mathrm{H}_{2} \mathrm{O}_{2}$-induced cell death of H9c2 examined using a cell counting kit. $\mathrm{H} 9 \mathrm{c} 2$ cells were treated with $100 \mu \mathrm{M}$ of $\mathrm{H}_{2} \mathrm{O}_{2}$ for 24 hours with or without OPG (1.5 and $\left.3 \mathrm{ng} / \mathrm{ml}\right)$ treatment. ${ }^{*} p<0.05$, \#p $<0.05$ compared to $\mathrm{H}_{2} \mathrm{O}_{2}$-treated group. (b) Expression of proapoptotic receptor TRAlL-R2 and activated (cleaved) caspase 8 in H9c2 cardiomyocytes exposed to $\mathrm{H}_{2} \mathrm{O}_{2}(100 \mu \mathrm{M})$ for 24 hours with or without OPG treatment (1.5 and $3 \mathrm{ng} / \mathrm{ml}$ ) examined by western blot analysis. (c) Effect of ASC conditioned media with or without $\mathrm{H}_{2} \mathrm{O}_{2}$ conditioning on the viability of $\mathrm{H} 9 \mathrm{c} 2$ cardiomyocytes exposed to $\mathrm{H}_{2} \mathrm{O}_{2}$. Normal conditioned media of ASC (NorCM) prepared by culturing ASCs for 48 hours and conditioned media with $\mathrm{H}_{2} \mathrm{O}_{2}$ conditioning $\left(\mathrm{H}_{2} \mathrm{O}_{2} \mathrm{CM}\right)$ prepared by culturing ASCs in the presence of $100 \mu \mathrm{M}$ of $\mathrm{H}_{2} \mathrm{O}_{2}$ for 48 hours. $\mathrm{H} 9 \mathrm{c} 2$ cells were cultured in NorCM or $\mathrm{H}_{2} \mathrm{O}_{2} \mathrm{CM}$ with or without addition of $100 \mu \mathrm{M}$ of $\mathrm{H}_{2} \mathrm{O}_{2}$ for 24 hours. ${ }^{*} p<0.05$, $\# p<0.05$ compared to $\mathrm{H}_{2} \mathrm{O}_{2}$-treated group. (d) Effect of ASC conditioned media with or without $\mathrm{H}_{2} \mathrm{O}_{2}$ conditioning on the viability of primary cardiomyocytes exposed to $\mathrm{H}_{2} \mathrm{O}_{2}$. The same experimental procedure used for H9c2 cardiomyocytes was applied to primary cardiomyocytes. ${ }^{*} p<0.05$, $\# p<0.05$ compared to $\mathrm{H}_{2} \mathrm{O}_{2}$-treated group. OPG osteoprotegerin, TRAIL-R2 tumor necrosis factor-related apoptosis-inducing ligand receptor 2

To test the hypothesis in vitro, we used $100 \mu \mathrm{M}$ of $\mathrm{H}_{2} \mathrm{O}_{2}$ to simulate oxidative stress to which both host cardiomyocytes and transplanted ASCs are exposed in vivo. In our study, $\mathrm{H}_{2} \mathrm{O}_{2}$ induced cardiomyocyte death via oxidative stress-mediated activation of apoptosis, confirming the validity of our experimental setting (Additional file 2: Figure S1). When ASCs were exposed to $\mathrm{H}_{2} \mathrm{O}_{2}$ or transplanted to I/R-injured heart, the production of OPG was significantly increased (Fig. 1), suggesting that ASCs exposed to a hostile microenvironment, such as I/R-injured heart, can produce OPG for the first few days following transplantation. Further experiments showed that OPG can suppress ROS-induced apoptosis of cardiomyocytes (Fig. 2a, b) and demonstrated that $\mathrm{H}_{2} \mathrm{O}_{2}$ conditioning of ASCs enhanced the protective effect of conditioned media possibly by increasing OPG production from ASCs (Fig. 2c, d). Experiments using OPG-specific siRNA indicated that the cell protective effect of ASC conditioned media was indeed OPG mediated (Fig. 3).

One interesting observation was that ASCs were less sensitive to $\mathrm{H}_{2} \mathrm{O}_{2}$ compared to cardiomyocytes (Additional file 3: Figure S2). This might have something to do with the increased OPG and TRAIL-R3 expression under oxidative stress (Additional file 4: Figure S3) because cotransfection of siRNAs specific to OPG and TRAIL-R3 significantly decreased the viability of ASCs exposed to $\mathrm{H}_{2} \mathrm{O}_{2}$ (Additional file 5: Figure S4). This also suggested that OPG and TRAIL-R3 may compensate each other in terms of suppressing TRAIL-mediated cell death in ASCs. Nevertheless, without any further experimental evidence, this can only be speculated at this point. We are currently working to elucidate more detailed underlying mechanisms of OPG-mediated cardiomyocyte protection and to validate and confirm the findings of this study in vivo for further studies. 

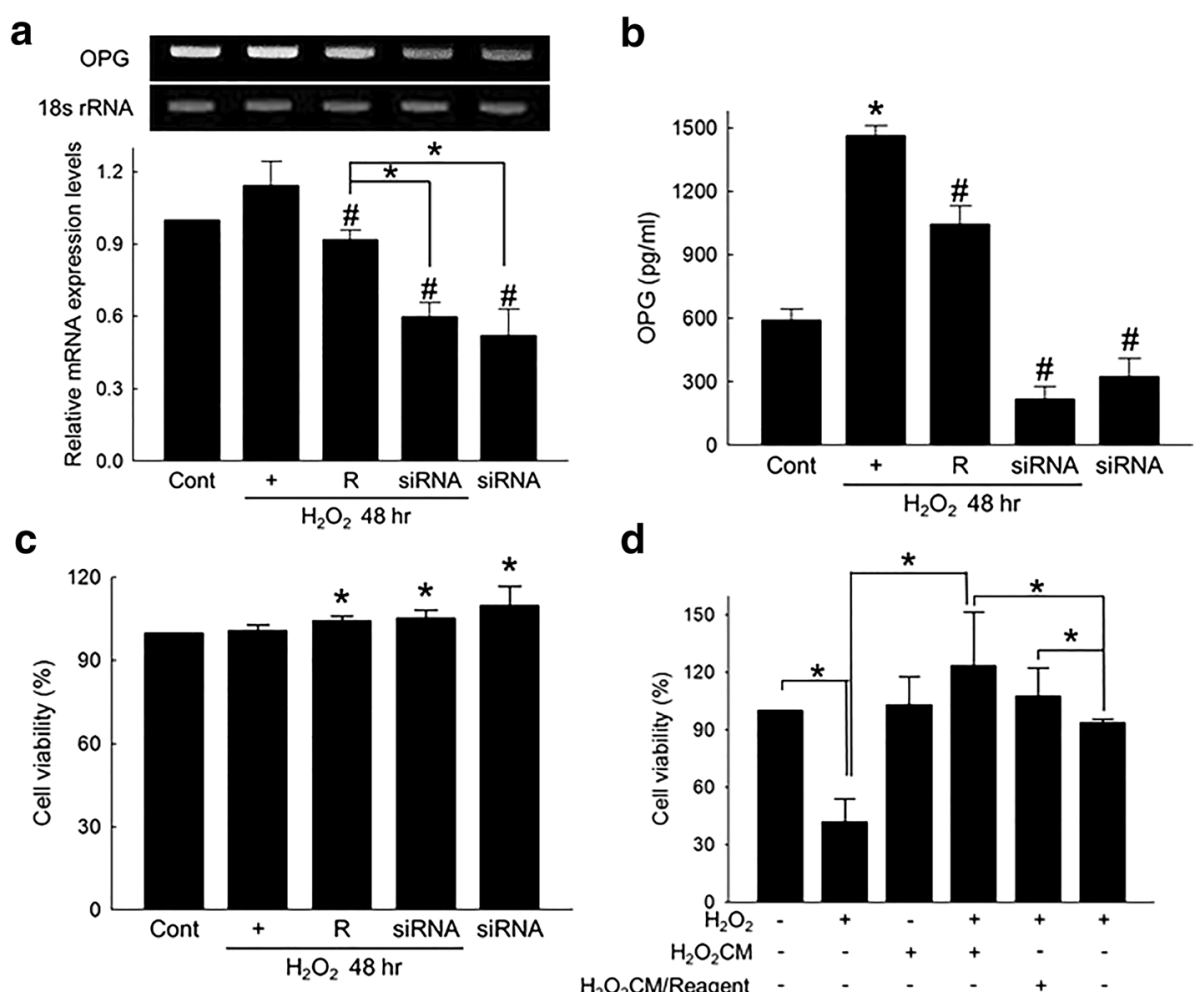

d

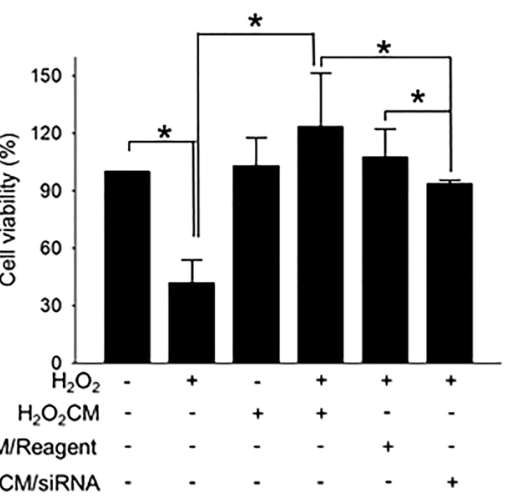

Fig. 3 Downregulation of OPG offset protective effect of ASC conditioned media. (a) OPG-siRNA-mediated downregulation of OPG in $\mathrm{H}_{2} \mathrm{O}_{2}$-treated ASCs. ASCs were transfected with $20 \mathrm{nM}$ of OPG-specific siRNA for 24 hours, and then exposed to $100 \mu \mathrm{M}$ of $\mathrm{H}_{2} \mathrm{O}_{2}$ for an additional 48 hours. mRNA expression of OPG normalized by $18 \mathrm{~s}$ rRNA expression. ${ }^{*} p<0.05$, \#p $<0.05$ compared to $\mathrm{H}_{2} \mathrm{O}_{2}$-treated group. (b) Effect of OPG-specific siRNA on the OPG production from ASCs exposed to $\mathrm{H}_{2} \mathrm{O}_{2}$. OPG-siRNA (20 nM)-transfected ASCs were cultured in the presence of $100 \mu \mathrm{M}$ of $\mathrm{H}_{2} \mathrm{O}_{2}$ for 48 hours, and the amount of OPG in ASC culture media was determined using an OPG-specific ELISA kit. ${ }^{*} p<0.05$ compared to untreated control, \#p<0.05 compared to $\mathrm{H}_{2} \mathrm{O}_{2}$-treated group. (c) Viability of OPG-siRNA-transfected ASCs exposed to $100 \mu \mathrm{M} \mathrm{of} \mathrm{H}_{2} \mathrm{O}_{2} \cdot{ }^{*} p<0.05$ compared to $\mathrm{H}_{2} \mathrm{O}_{2}$-treated group. (d) Effect of three different types of $\mathrm{H}_{2} \mathrm{O}_{2} \mathrm{CMs}$ on $\mathrm{H}_{2} \mathrm{O}_{2}$-induced cell death of $\mathrm{H} 9 \mathrm{c} 2$ cells. ${ }^{*} p<0.05$. $\mathrm{H}_{2} \mathrm{O}_{2} \mathrm{CM}$ ASC conditioned media prepared by culturing ASCs with $100 \mu \mathrm{M}$ of $\mathrm{H}_{2} \mathrm{O}_{2}$ for 48 hours, $\mathrm{H}_{2} \mathrm{O}_{2} \mathrm{CM}$ /Reagent conditioned media obtained using transfection reagent-treated ASCs, $\mathrm{H}_{2} \mathrm{O}_{2} \mathrm{CM} /$ siRNA conditioned media obtained using OPG-specific siRNA-transfected ASCs, OPG osteoprotegerin

\section{Conclusion}

In the present study we provided evidence that OPG is an ASC-released soluble factor that can protect cardiomyocytes from ROS-induced apoptosis for the first time. The results of this study warrant further studies to fully elucidate the exact nature of stem cell-released paracrine factors and may help us to design an effective stem cellbased therapeutic strategy in the future.

\section{Additional files}

Additional file 1: Describes additional methods including primers used for RT-PCR. (DOCX 34 kb)

Additional file 2: Figure S1. Showing ROS-induced cardiomyocyte death. (A) Viability of H9c2 cardiomyocytes exposed to increasing concentration of $\mathrm{H}_{2} \mathrm{O}_{2}$ for 24 hours. * $p<0.05$ compared to untreated control. (B) Effect of $\mathrm{H}_{2} \mathrm{O}_{2}$ on viability of primary cardiomyocytes. ${ }^{*} p<0.05$ compared to untreated control. (C) Expression of activated (cleaved) caspase 3 and 8 in $\mathrm{H} 9 \mathrm{c} 2$ cardiomyocytes exposed to $\mathrm{H}_{2} \mathrm{O}_{2}(100 \mu \mathrm{M})$ for 24 hours with or without antioxidant $\mathrm{N}$-acetyl-L-cystein (NAC) (1.5 mM). (D) Viability of
H9c2 cardiomyocytes exposed to $\mathrm{H}_{2} \mathrm{O}_{2}(100 \mu \mathrm{M})$ for 24 hours with or without antioxidant NAC (1.5 mM). ${ }^{*} p<0.05$. (E) Flow cytometry analysis of $\mathrm{H} 9 \mathrm{c} 2$ cardiomyocytes exposed to $\mathrm{H}_{2} \mathrm{O}_{2}(100 \mu \mathrm{M})$ for 24 hours with or without antioxidant NAC (1.5 mM). PI propidium iodide. (PDF $237 \mathrm{~kb}$ )

Additional file 3: Figure S2. Showing effect of $\mathrm{H}_{2} \mathrm{O}_{2}$ on ASC viability. ${ }^{*} p<0.05$ compared to control. (PDF $36 \mathrm{~kb}$ )

Additional file 4: Figure S3. Showing ROS-induced OPG and TRAIL-R3 expression in ASCs. ${ }^{*} p<0.05$ compared to corresponding control of each group. (PDF $160 \mathrm{~kb}$ )

Additional file 5: Figure S4. Showing that OPG and TRAIL-R3 contribute to the survival of ASCs exposed to ROS. (A) Expression of TRAIL-R3 mRNA 24 hours after transfection of siRNA specific to TRAIL-R3. 18 s-rRNA used as internal control. (B) Effect of OPG and/or TRAIL-R3 downregulation on the viability of ASCs exposed ROS. Cells transfected with OPG siRNA and/or TRAlLR3 siRNA for 24 hours and then exposed to $\mathrm{H}_{2} \mathrm{O}_{2}(100$ and $200 \mu \mathrm{M})$ for an additional 24 hours. * $p<0.05$ compared to untreated control. (PDF 87 kb)

\section{Abbreviations}

ASC: Adipose-derived stem cell; DMEM: Dulbecco's modified Eagle's medium; ELISA: Enzyme-linked immunosorbent assay; FBS: Fetal bovine serum; $\mathrm{H}_{2} \mathrm{O}_{2} \mathrm{CM}$ : ASC conditioned media with $\mathrm{H}_{2} \mathrm{O}_{2}$ conditioning; I/R: Ischemia-reperfusion; NAC: $\mathrm{N}$-acetylcystein; NorCM: ASC conditioned media without $\mathrm{H}_{2} \mathrm{O}_{2}$ conditioning; OPG: Osteoprotegerin; PBS: Phosphate-buffered saline; 
ROS: Reactive oxygen species; TGF- $\beta 1$ : Transforming growth factor beta 1; TNF: Tumor necrosis factor; TRAIL: Tumor necrosis factor-related apoptosis-inducing ligand; TRAIL-R1-R4: TRAIL receptor 1-4

\section{Acknowledgements}

Not applicable.

\section{Funding}

This study was supported by grants funded by the Korea Ministry of Science, ICT and Future Planning (NRF-2011-0019254 and NRF-2015M3A9E6029519) and a grant from the Korea Health 21 R\&D Project, Ministry of Health \& Welfare, Republic of Korea (A120478).

\section{Availability of data and materials}

All data supporting the conclusions of this article are included within the article and its supplementary files.

\section{Authors' contributions}

$J L$ and SLee conceived the study, participated in all experiments, and revised the manuscript. CYL, HHS, and SS participated in in-vitro and in-vivo testing. JWC and SWK participated in in-vitro testing and made significant contribution to revising the manuscript. JCP participated in the study design and provided technical assistance. SLim and KCH conceived the study, participated in the study design, and drafted and edited the manuscript. All authors read and approved the final manuscript.

\section{Ethics approval and consent to participate}

Not applicable.

\section{Consent for publication}

All authors declare their support for the publication and its contents.

\section{Competing interests}

The authors declare that they have no competing interests.

\section{Publisher's Note}

Springer Nature remains neutral with regard to jurisdictional claims in published maps and institutional affiliations.

\section{Author details}

'Brain Korea 21 PLUS Project for Medical Science, Yonsei University, Seoul, Korea. ${ }^{2}$ Institute for Bio-Medical Convergence, College of Medicine, Catholic Kwandong University, Gangneung, Gangwon-do, Korea. ${ }^{3}$ Department of Integrated Omics for Biomedical Sciences, Yonsei University, Seoul, South Korea. ${ }^{4}$ Department of Environmental Engineering, Catholic Kwandong University, Gangneung-si, Gangwon-do, Republic of Korea. ${ }^{5}$ Cellbiocontro Laboratory, Department of Medical Engineering, Yonsei University College of Medicine, Seoul, Republic of Korea.

Received: 26 May 2017 Revised: 1 August 2017

Accepted: 14 August 2017 Published online: 19 September 2017

\section{References}

1. Rasmussen JG, Frobert O, Holst-Hansen C, Kastrup J, Baandrup U, Zachar V, et al. Comparison of human adipose-derived stem cells and bone marrowderived stem cells in a myocardial infarction model. Cell Transplant. 2014; 23(2):195-206. doi:10.3727/096368912X659871

2. Paul A, Srivastava S, Chen G, Shum-Tim D, Prakash S. Functional assessment of adipose stem cells for xenotransplantation using myocardial infarction immunocompetent models: comparison with bone marrow stem cells. Cell Biochem Biophys. 2013;67(2):263-73. doi:10.1007/s12013-011-9323-0.

3. Burdon TJ, Paul A, Noiseux N, Prakash S, Shum-Tim D. Bone marrow stem cell derived paracrine factors for regenerative medicine: current perspectives and therapeutic potential. Bone Marrow Res. 2011;2011:207326. doi:10.1155/ 2011/207326.

4. Song SW, Kim KE, Choi JW, Lee CY, Lee J, Seo HH, et al. Proteomic analysis and identification of paracrine factors in mesenchymal stem cell-conditioned media under hypoxia. Cell Physiol Biochem. 2016;40(1-2):400-10. doi:10.1159/ 000452555.

5. Hsiao ST, Asgari A, Lokmic Z, Sinclair R, Dusting GJ, Lim SY, et al. Comparative analysis of paracrine factor expression in human adult mesenchymal stem cells derived from bone marrow, adipose, and dermal tissue. Stem Cells Dev. 2012;21(12):2189-203. doi:10.1089/scd.2011.0674.

6. Hwang HJ, Chang W, Song BW, Song H, Cha MJ, Kim IK, et al. Antiarrhythmic potential of mesenchymal stem cell is modulated by hypoxic environment. J Am Coll Cardiol. 2012;60(17):1698-706. doi:10.1016/j.jacc.2012.04.056.

7. Corallini F, Celeghini C, Rimondi E, di lasio MG, Gonelli A, Secchiero P, et al. Trail down-regulates the release of osteoprotegerin (OPG) by primary stromal cells. J Cell Physiol. 2011;226(9):2279-86. doi:10.1002/jcp.22564.

8. Emery JG, McDonnell P, Burke MB, Deen KC, Lyn S, Silverman C, et al. Osteoprotegerin is a receptor for the cytotoxic ligand TRAIL. J Biol Chem. 1998:273(23):14363-7.

9. Wang S, El-Deiry WS. TRAIL and apoptosis induction by TNF-family death receptors. Oncogene. 2003;22(53):8628-33. doi:10.1038/sj.onc.1207232.

10. Buneker C, Mohr A, Zwacka RM. The TRAlL-receptor-1: TRAlL-receptor-3 and -4 ratio is a predictor for TRAlL sensitivity of cancer cells. Oncol Rep. 2009;21(5):1289-95.

11. Fu J, Gao J, Pi R, Liu P. An optimized protocol for culture of cardiomyocte from neonatal rat. Cytotechnology. 2005;49:109-16. do:10.1007/s10616-006-6334-6.

12. Gough DR, Cotter TG. Hydrogen peroxide: a Jekyll and Hyde signalling molecule. Cell Death Dis. 2011;2:e213. doi:10.1038/cddis.2011.96.

13. Gille JJ, Joenje H. Cell culture models for oxidative stress: superoxide and hydrogen peroxide versus normobaric hyperoxia. Mutat Res. 1992;275(3-6):405-14

14. Watkins SJ, Borthwick GM, Arthur HM. The H9C2 cell line and primary neonatal cardiomyocyte cells show similar hypertrophic responses in vitro. In Vitro Cell Dev Biol Anim. 2011:47(2):125-31. doi:10.1007/s11626-010-9368-1.

15. Zafarullah M, Li WQ, Sylvester J, Ahmad M. Molecular mechanisms of N-acetylcysteine actions. Cell Mol Life Sci. 2003;60(1):6-20.

16. Cornelissen M, Philippe J, De Sitter S, De Ridder L. Annexin V expression in apoptotic peripheral blood lymphocytes: an electron microscopic evaluation. Apoptosis. 2002;7(1):41-7.

17. Pardali E, Ten Dijke P. TGFbeta signaling and cardiovascular diseases. Int J Biol Sci. 2012;8(2):195-213. doi:10.7150/ijbs.3805.

18. Ashkenazi A, Dixit VM. Apoptosis control by death and decoy receptors. Curr Opin Cell Biol. 1999:11(2):255-60

19. Jeremias I, Kupatt C, Martin-Villalba A, Habazettl H, Schenkel J, Boekstegers $\mathrm{P}$, et al. Involvement of CD95/Apo 1/Fas in cell death after myocardial ischemia. Circulation. 2000;102(8):915-20.

20. Braunersreuther $\mathrm{V}$, Jaquet $\mathrm{V}$. Reactive oxygen species in myocardial reperfusion injury: from physiopathology to therapeutic approaches. Curr Pharm Biotechnol. 2012;13(1):97-114.

21. Kalogeris T, Baines CP, Krenz M, Korthuis RJ. Cell biology of ischemia/ reperfusion injury. Int Rev Cell Mol Biol. 2012;298:229-317. doi:10.1016/ B978-0-12-394309-5.00006-7.

22. Sugamura K, Keaney Jr JF. Reactive oxygen species in cardiovascular disease Free Radic Biol Med. 2011:51(5):978-92. doi:10.1016/f.freeradbiomed.2011.05.004.

23. Webster KA. Mitochondrial membrane permeabilization and cell death during myocardial infarction: roles of calcium and reactive oxygen species. Future Cardiol. 2012;8(6):863-84. doi:10.2217/fca.12.58.

\section{Submit your next manuscript to BioMed Central and we will help you at every step:}

- We accept pre-submission inquiries

- Our selector tool helps you to find the most relevant journal

- We provide round the clock customer support

- Convenient online submission

- Thorough peer review

- Inclusion in PubMed and all major indexing services

- Maximum visibility for your research

Submit your manuscript at www.biomedcentral.com/submit

\section{BioMed Centra}

